\title{
Neurothekoma of the scalp
}

\section{Olfa El Amine El Hadj', Leila Bouhajja', Aida Goucha1, Jameleddine Ben Hassouna², Wafa Rekik', Ahmed El May', Amor Gamoudi'}

${ }^{1}$ Department of Pathology, Carcinological Institute Salah Azaiez, Tunis, Tunisia, ${ }^{2}$ Department of Carcinological Surgery, Carcinological Institute Salah Azaiez, Tunis, Tunisia

Corresponding author: Dr. Olfa El Amine El Hadj, E-mail: olfaelamine@yahoo.fr

Sir,

We report a 30 year-old woman with a history of lumpectomy for a benign breast tumor, presented with a 10-year history of an exophytic lesion of the scalp. The physical examination revealed a giant mass on the scalp, which was immobile, tender and exhibited distinct borders. A total excision of the lesion was performed. Grossly, the tumor was nodular, exophytic, and measured $19 \mathrm{~cm}$ of diameter. Histological examination showed a tumor consisting of spindle to epitheloid cells forming micro nodules in a concentric whorled shape pattern (Fig l) embedded in abundant myxoïd stroma (Fig. 2). These features confirmed the diagnosis of a neurothekoma. At 3 years of follow-up, the patient was asymptomatic and there was no recurrence.

The patient's informed consent was obtained.

Prior to the study, patient gave written consent to the examination and biopsy after having been informed about the procedure.

Neurothekoma (NT) is an uncommon and benign dermal tumor, originating from the sheath of peripheral nerves. It is mainly located on the face, neck, arms and shoulders of young adults, and is more frequent in females $[1,2]$.

Clinically, it manifests as an asymptomatic, pinkerythematous, dome-shaped, solitary papule or nodule, with a slow growth rate [2]. The clinical differential diagnosis of NT includes epidermal cyst, dermatofibroma, adnexal tumor (e.g. pilomatricoma), Fibrohistiocytic tumor, Basal cell carcinoma, hemangioma, amelanotic melanoma and cutaneous metastasis [2].

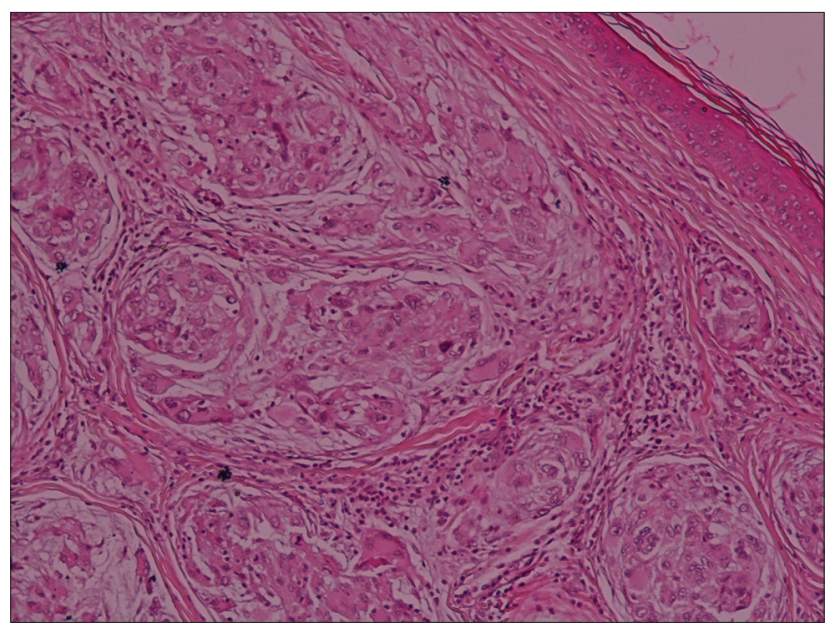

Figure 1: Subcutaneous layer containing whorls of regular fusiform cells.

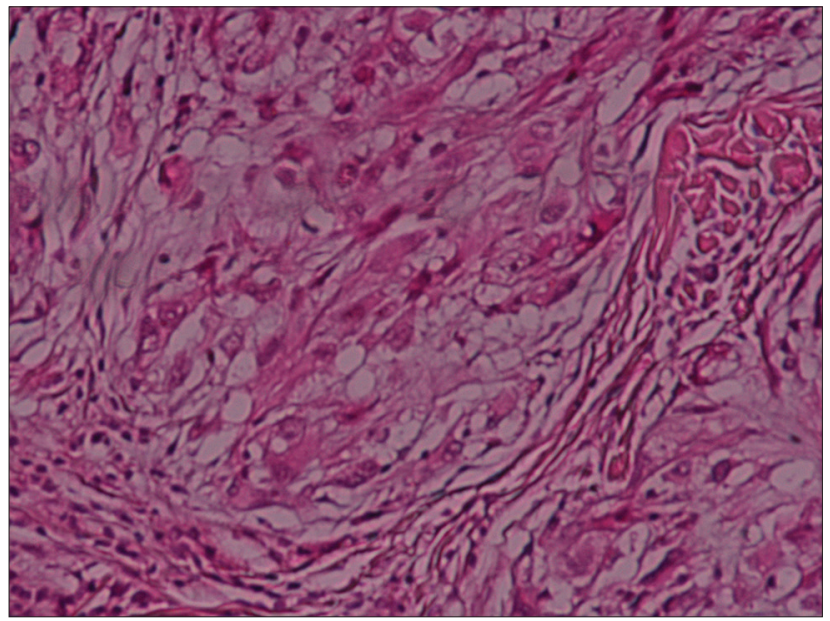

Figure 2: Epitheloid and fusiform cells embedded into a myoid stroma.

Histological examination shows the presence of spindle and epithelioid cells with abundant granulareosinophilic cytoplasm and a tendency to be grouped in whorled nodules spared by collagen bundles in the dermis and subcutaneous area. There may be sclerotic

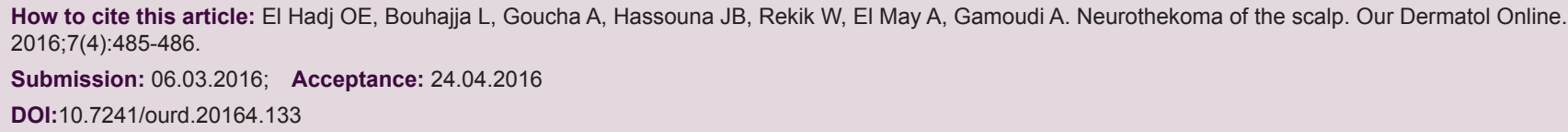


collagen and osteoclast-like cells [3]. Furthermore, this tumor is subclassified histopathologically into 3 groups: myxoid, mixed, and cellular type depending on the amount of myxoid matrix [4]. Immunohistochemically, the $\mathrm{S} 100$ protein is useful to differenciate the myxoid type from the cellular type. The tumor cells of the cellular variant are not generally stained with markers for nerve-origin cells, but are positively stained with NKI/C3, Ki-Mlp, and CD68 [4].

The histological differencial diagnosis includes melanocytic tumor variants (e.g. Spitz Nevus), neurofibroma, schwannoma or neuroma variants [2]. An atypical variant of NT has recently been described. It is described like a larger tumor (up to $6 \mathrm{~cm}$ ) of deep penetration (skeletal muscle and subcutaneous fat involvement), diffuse infiltrative borders, vascular invasion, a high mitotic index (>3 mitosis per 10 high power fields) and pleomorphism [5].

The real recurrence of NT is around 3\%. Risk factors for recurrence are: myxoid type, being female, facial location, younger age at diagnosis, positive margins, and absence of fat-tissue in the sample [3].

\section{CONCLUSION}

Neurothekoma is a rare tumor. The diagnosis is based on histopathological and eventually immunohistichemical exam. The evolution is marked by the risk of recidive.

\section{Consent}

The examination of the patient was conducted according to the Declaration of Helsinki principles. Written informed consent was obtained from the patient for publication of this article

\section{REFERENCES}

1. Ding YI, Zou F, Peng W, Dai M, Gu H, Zhang B, et al. A giant neurothekeoma of the left shoulder blade: A case report Oncol Lett. 2016;11:1130-34.

2. Navarrete-Dechent C, Curi-Tuma M, Marín C, González S, SandovalOsses M. Cellular neurothekeoma: case report and its relation with nerve sheath myxoma An Bras Dermatol. 2015;90:156-59.

3. Fetsch JF, Laskin WB, Hallman JR, Lupton GP, Miettinen M. Neurothekeoma: an analysis of 178 tumors with detailed immunohistochemical data and long-term patient follow-up information. Am J Surg Pathol. 2007;31:1103-14.

4. Yun SJ, Park HS, Lee JB, Kim SJ, Lee SC, Won YH. Myxoid Cellular Neurothekeoma: A New Entity of S100-Negative, CD68-Positive Myxoid Neurothekeoma. Ann Dermatol. 2014;26:510-13.

5. Campanati A, Brandozzi G, Sisti S, Bernardini ML, Offidani AM. Atypical neurothekeoma: a new case and review of the literature. J Cutan Pathol. 2007;34:435-37.

Copyright by Olfa El Amine El Hadj, et al. This is an open access article distributed under the terms of the Creative Commons Attribution License, which permits unrestricted use, distribution, and reproduction in any medium, provided the original author and source are credited.

Source of Support: Nil, Conflict of Interest: None declared. 